\title{
Interferons Modulate the Expression of Hormone Receptors on the Surface of Murine Melanoma Cells
}

\author{
Koichiro Kameyama, * Syuji Tanaka," Yasuo Ishida, ${ }^{\ddagger}$ and Vincent J. Hearing* \\ ${ }^{*}$ Laboratory of Cell Biology, National Cancer Institute and ${ }^{\ddagger}$ Laboratory of Immunology, National Institute of Allergy \\ and Infectious Diseases, National Institutes of Health, Bethesda, Maryland 20892
}

\begin{abstract}
The effects of IFN- $\alpha$, IFN- $\beta$, and IFN- $\gamma$ on the differentiation of murine melanoma cells has been studied, in the presence and absence of melanocyte-stimulating hormone (MSH); the cells were highly responsive to treatment with MSH, which increased the rate of melanin production 25 -fold and tyrosinase activity 6-fold within $4 \mathrm{~d}$. Treatment of melanoma cells with IFN- $\alpha$, IFN- $\beta$, or IFN- $\gamma$ alone had no stimulatory effect on melanin production, but when the cells were cultured with IFN in the presence of MSH, pigment production was significantly and synergistically increased relative to cells cultured with MSH only. Flow cytometric analysis revealed that levels of tyrosinase in the cells were not affected by MSH or by IFN, which suggests that stimulation of melanogenic activity occurred by activation of a preexisting cellular enzyme. Scatchard analyses showed that the number of MSH receptors on IFN-treated cells was significantly increased $(\sim 2.5$-fold $)$ relative to untreated cells $(\sim 61,000 /$ cell $)$. These findings demonstrate that IFN stimulate differentiation (that is, pigmentation) of melanocytes by increasing the expression of surface MSH receptors; this in turn suggests that such a mechanism may in part be responsible for postinflammatory skin pigmentation, and provides an additional basis for action in the clinical responses of melanoma to IFN treatment.
\end{abstract}

\section{Introduction}

The phenomenon of postinflammatory skin pigmentation has been observed after various kinds of inflammatory skin disease, such as contact dermatitis and drug eruptions, although the mechanism(s) involved have not yet been explained. These diseases have a common histologic feature, the presence of inflammatory cells in the skin. Inflammatory cells are composed of lymphocytes, monocytes, and neutrophils, all of which produce IFN (1); in addition, lymphocytes infiltrating dysplastic nevi or melanoma lesions have been shown to produce IFN- $\gamma(2)$. IFN have been reported to promote differentiation of various kinds of cells including myoblasts (3), histiocytic lymphoma cells (4), and promyelocytic leukemia cells (5). IFN have been reported in some studies to increase pigment production by melanoma cells $(6-8)$, but in others, to

Dr. Kameyama's permanent address is the Department of Dermatology, Kitasato University School of Medicine, 1-15-1 Kitasato, Sagamihara 228, Japan.

Address reprint requests to Dr. Vincent Hearing, Building 37, Room 1B22, National Institutes of Health.

Received for publication 28 March 1988 and in revised form 21 July 1988.

The Journal of Clinical Investigation, Inc.

Volume 83, January 1989, 213-221 reduce it (9-11). The specific effects of IFN on melanogenesis thus have not yet been conclusively determined. Such studies suggest the possibility that IFN may elicit postinflammatory skin pigmentation by stimulating differentiation, and thus pigmentation, of epidermal melanocytes. As a result, IFN have been used as potential antimelanoma agents in both animal models and clinical trials (12-14).

Melanocytes are highly suitable models for studies of differentiation because melanin is a specific, readily visible, and identifiable product; the melanin pigment is produced by an enzyme termed tyrosinase (EC 1.14.18.1), which in turn can be quantitated rather easily. There are also many physiologically relevant agents that can induce differentiation in mammalian melanocytes in vivo and in vitro, including ultraviolet light and melanocyte-stimulating hormone (MSH). ${ }^{1}$ Ideally, studies of differentiation would use normal melanocytes, but because these cells are sparse in mammals, and are very difficult if not impossible to culture in significant quantity, most studies on melanogenesis have relied on the use of murine melanomas, such as the B16, S91, and Harding-Passey. Those tumor lines were established $>30 \mathrm{yr}$ ago, and thus there is a possibility that they have drifted significantly in phenotype, and no longer resemble the original pigmented tumors. Recently, the JB/MS melanoma was induced by carcinogens (15, 16); this tumor has now been adapted to tissue culture, and is a highly pigmented, relatively well-differentiated cell line, which has been proposed to serve as a more appropriate model for melanogenic and tumorigenic studies (15-18). In this report, JB/MS murine melanoma cells, as well as B16 and S91 cells, were used to investigate the effect of IFN on spontaneous and MSH-induced pigmentation. We have found that IFN- $\alpha$, IFN- $\beta$, and IFN- $\gamma$ stimulate the expression of MSH receptors on the surface of melanoma cells; this enhanced binding capacity for MSH is followed by a significant synergistic stimulation of melanin production in the presence of $\mathrm{MSH}$.

\section{Methods}

Materials. Natural murine IFN- $\alpha\left(1.4 \times 10^{6} \mathrm{IU} / \mathrm{mg}\right)$ and IFN- $\beta(5.6$ $\times 10^{7} \mathrm{IU} / \mathrm{mg}$ ) were purchased from Lee Biomolecular Research (San Diego, CA $)$; murine rIFN- $\gamma\left(1.2 \times 10^{7} \mathrm{IU} / \mathrm{mg}\right)$ was supplied by Genentech (19) (South San Francisco, CA). Purified synthetic $\alpha$-MSH was a gift from Dr. J. Pawelek (Yale University, New Haven, CT), and was also purchased from Calbiochem-Behring Corp. (La Jolla, CA).

Cell culture. The recently derived, 7,12-dimethylbenzanthracene induced JB/MS melanoma $(15,16)$ was used in this study; the growth characteristics and culture methods for this cell line have been described in detail elsewhere $(17,18)$. In these experiments, JB/MS cells (at passage 6) were cultured a maximum of 2 mo; continual passage longer than this resulted in significant phenotypic drift (unpublished

1. Abbreviations used in this paper: MSH, melanocyte-stimulating hormone. 
observations). We have also used B16 and S91 murine melanoma cells in some experiments; these were derived as previously noted (18). DME and other tissue culture supplies were purchased from Gibco Laboratories (Grand Island, NY); our routine culture medium consisted of DME supplemented with $10 \%$ heat-inactivated, mycoplasma and virus-free $\mathrm{FCS}, 100 \mu \mathrm{g} / \mathrm{ml}$ streptomycin, $100 \mathrm{U} / \mathrm{ml}$ penicillin, and $0.25 \mu \mathrm{g} / \mathrm{ml}$ amphotericin-B, nonessential amino acids, and glutamine. Unless otherwise noted, cells were harvested in exponential growth phase with trypsin/EDTA, and seeded at a concentration of $6 \times 10^{5}$ cells per $75-\mathrm{cm}^{2}$ flask. The cells were maintained in a humidified incubator with $5 \% \mathrm{CO}_{2}$ in air at $37^{\circ} \mathrm{C} .24 \mathrm{~h}$ later (day 0 ) the medium was removed and replaced with fresh medium containing IFN and/or MSH at the concentrations noted in the tables and figures; the appropriate medium was changed daily thereafter. MSH was routinely used (except as reported in Table IV) at $2 \times 10^{-7} \mathrm{M}$; this concentration has been shown to elicit maximal melanogenic response in murine melanoma cells, as previously reported (20-22).

Determination of melanogenic activities. Melanogenic activities were measured by two radiometric assays as previously described (23, 24); briefly, cells were harvested with trypsin/EDTA, and then solubilized at a concentration of $10^{5}$ cells per $30 \mu \mathrm{l}$ with $1 \% \mathrm{NP}-40$ for $1 \mathrm{~h}$ at $4^{\circ} \mathrm{C}$. The cell extracts were then centrifuged at $12,000 \mathrm{~g}$ for $10 \mathrm{~min}$, and $30 \mu \mathrm{l}$ of the soluble extract (i.e., $10^{5}$ cell equivalents) were incubated with $10 \mu \mathrm{l}$ labeled tyrosine ( $50 \mu \mathrm{M}$ as noted below) and $10 \mu \mathrm{l}$ of DOPA cofactor $(50 \mu \mathrm{M})$ at $37^{\circ} \mathrm{C}$ in a 96 -well microtiter plate. For analysis of melanin formation, $\mathrm{L}-\left[U_{-}{ }^{14} \mathrm{C}\right]$ tyrosine $(100 \mathrm{mCi} / \mathrm{mmol}, 25$ $\mu \mathrm{Ci} / \mathrm{ml}$; New England Nuclear, Boston, MA) was used; after the incubation, $20 \mu$ l were removed to filter discs and washed three times with $0.1 \mathrm{~N} \mathrm{HCl}$, two times with ethanol, and once with acetone. The discs were then dried and the radioactive, acid-insoluble melanin that had been formed was measured in a liquid scintillation counter. The data reported in the tables used a $16-\mathrm{h}$ incubation, but in separate experiments, we have determined that rates of melanin production are linear throughout that time period. For analysis of tyrosinase activity, L[3,5- $\left.{ }^{3} \mathrm{H}\right]$ tyrosine $(1 \mathrm{Ci} / \mathrm{mmol}, 250 \mu \mathrm{Ci} / \mathrm{ml}$; New England Nuclear) was used; after $1 \mathrm{~h}$ incubation, $20 \mu \mathrm{l}$ was removed and added to $980 \mu \mathrm{l} 0.1$ $\mathrm{N} \mathrm{HCl}$ with activated charcoal and Celite 545 in $12 \times 75 \mathrm{~mm}$ tubes; after mixing for $1 \mathrm{~h}$ at $23^{\circ} \mathrm{C}$, the tubes were centrifuged for $1,300 \mathrm{~g}$ for $10 \mathrm{~min}$, and the $\left[{ }^{3} \mathrm{H}\right]$ water that had been formed as the result of tyrosine hydroxylation (which remains in the supernatant) was measured in a scintillation counter. Enzyme assays were carried out at least in triplicate and variability within the assays was always $< \pm 15 \%$; backgrounds were established by omitting either the enzyme sample or the cofactor. In related experiments (not shown), we have determined that neither MSH nor IFN has any effect on either of the two radiometric assays described above.

Flow cytometric analysis. Cells were harvested with $0.02 \%$ EDTA in HBSS and permeabilized with $70 \%$ ethanol for $30 \mathrm{~min}$ at $4^{\circ} \mathrm{C} ; 10^{6}$ cells were reacted with $50 \mu \mathrm{l}$ tyrosinase-specific MAb TMH-1 for $1 \mathrm{~h}$ at $4^{\circ} \mathrm{C}$; the specificity and reactivity of TMH-1 for mammalian tyrosinase has been previously reported $(18,25)$. After the incubation, the cells were washed twice in HBSS and then reacted with $40 \mu$ l fluorescein isothiocyanate-conjugated rabbit IgG anti-rat IgG (diluted 1:20 in HBSS; Dako Corp., Santa Barbara, CA). The cells were then again washed twice in HBSS and finally resuspended in HBSS and analyzed with a FACS II (Becton Dickinson \& Co., Mountain View, CA). Nonspecific background staining was determined by omitting the first antibody and/or by staining of nonmelanocytic cells.

Iodination and purification of MSH. These techniques were performed using a modified procedure of Lambert and Lerner (26); briefly, $2.2 \mu \mathrm{g}$ of Iodogen (Pierce Chemical Co., Rockford, IL) in $20 \mu \mathrm{l}$ dichloromethane was plated on the bottom of $12 \times 75 \mathrm{~mm}$ glass tubes, and then evaporated. Each iodination was carried out in one of these tubes at $4^{\circ} \mathrm{C}$, and the reaction mixture consisted of $5 \mathrm{mCi} \mathrm{Na}\left[{ }^{125} \mathrm{I}\right]$ (New England Nuclear) in $10 \mu \mathrm{l} 0.1 \mathrm{M} \mathrm{NaOH}, 100 \mu \mathrm{l} 0.1 \mathrm{M}$ borate buffer, $\mathrm{pH} 8.2$, and $11 \mu \mathrm{l}(6.5 \mathrm{nmol})$ of $\mathrm{MSH}$. The reaction was terminated after $20 \mathrm{~min}$ by removing the reaction mixture from the tube and adding it to $0.9 \mathrm{ml}$ borate-buffered saline containing $0.75 \mathrm{M}$ DTT and
$100 \mu \mathrm{g} / \mathrm{ml}$ gentamycin; this solution was passed through a $(22 \times 0.45$ cm) Sephadex G10 column (Pharmacia Fine Chemicals, Piscataway, NJ) and eluted with DTT/gentamycin borate-buffered saline. The first radioactive peak fractions were pooled and incubated at $37^{\circ} \mathrm{C}$ for $24 \mathrm{~h}$ to reduce oxidized methionine and maintain biological activity. The mixtures were then further purified by HPLC (model 344; Beckman Instruments, Fullerton, CA) equipped with a $25 \times 0.45 \mathrm{~cm}$ Altex C18 reverse-phase column; the components of the mixture were eluted from the column at $1 \mathrm{ml} / \mathrm{min}$ using a linear gradient of increasing acetonitrile from 6 to $60 \%$ in $0.01 \mathrm{M}$ trifluoroacetic acid, and the elution was monitored at $280 \mathrm{~nm}$. The eluted material was collected in 30 -s fractions and monitored for radioactivity in a $\gamma$ counter. The purified $\left[{ }^{125} \mathrm{I}\right]-\mathrm{MSH}$ prepared in this manner had a specific activity of $75-150 \mu \mathrm{Ci} / \mu \mathrm{g}$.

Amino acid analysis. Amino acid analysis was performed as previously described (27). Briefly, peptides were hydrolyzed with $6 \mathrm{~N} \mathrm{HCl}$ containing $0.1 \%$ phenol for $24 \mathrm{~h}$ at $110^{\circ} \mathrm{C}$, after which the dried hydrolysates were derivatized with phenylthiocarbamyl; these derivatives were then analyzed using a Waters Picotag amino acid analysis system (Waters Associates, Milford, MA).

Biologic activity of iodinated MSH. $2 \times 10^{5} \mathrm{JB} / \mathrm{MS}$ cells were seeded into $25-\mathrm{cm}^{2}$ flasks and $24 \mathrm{~h}$ later, the medium in each flask was removed and replaced with $5 \mathrm{ml}$ fresh medium containing various concentrations of unlabeled MSH or ${ }^{125} \mathrm{I}$-MSH. $48 \mathrm{~h}$ later, the medium in each flask was again changed, and $48 \mathrm{~h}$ later, the media were removed and the cells in the flasks were harvested with trypsin/EDTA. The cells were then solubilized as detailed above and assayed for tyrosinase activity. After incubation, the aliquots were checked with a $\gamma$ counter to measure $\left[{ }^{125} \mathrm{I}\right]$ contamination (slight levels were found in extracts of cells that had received the highest concentrations of labeled MSH). The samples were then processed as detailed above to measure $\left[{ }^{3} \mathrm{H}\right]$ water formation, and again checked for contaminating $\left[{ }^{125} \mathrm{I}\right]$ (which was no longer detectable).

Receptor binding assay. Binding of the labeled MSH to surface receptors was measured by a modification of the method of Lambert et al. (28). Briefly, this involves harvesting the cells with EDTA as detailed above, and washing them twice with HBSS; the cells are then resuspended in binding buffer, which consists of $0.5 \%$ BSA in DME, pH 6.8. The cells were centrifuged again, resuspended in fresh binding buffer, and cooled to $4^{\circ} \mathrm{C}$. Known volumes of the suspension were then mixed with binding buffer containing $\left[{ }^{125} I\right]-M S H$ (to determine total binding of the ligand) or with [ $\left.{ }^{125} \mathrm{I}\right]-\mathrm{MSH}$ plus a 1,000 -fold excess of unlabeled MSH (to determine specific and nonspecific binding of the ligand). For all experiments, the incubation mixture had $1.5 \times 10^{6}$ cells in a final volume of $750 \mu \mathrm{l}$ in $12 \times 75 \mathrm{~mm}$ siliconized glass tubes; these were incubated for $2 \mathrm{~h}$ at $4^{\circ} \mathrm{C}$ with gentle shaking (unless otherwise noted). After determination of the total label in each tube in a $\gamma$ counter, the cell-bound [ $\left.{ }^{125} \mathrm{I}\right]-\mathrm{MSH}$ was separated from free ligand in the following manner: $200-\mu l$ aliquots from each tube were layered over discontinuous sucrose gradients $(150 \mu \mathrm{l} 0.3 \mathrm{M}$ sucrose overlaid with $100 \mu \mathrm{l} 0.15 \mathrm{M}$ sucrose in $0.5 \mathrm{ml}$ microcentrifuge tubes) and centrifuged in a microfuge (model 5412; Brinkmann Instruments, Westbury, NY) for $10 \mathrm{~s}$. After a further washing with $450 \mu$ labeling buffer, the $\left[{ }^{125} \mathrm{I}\right]-\mathrm{MSH}$ associated with the cell pellets was determined with a $\gamma$ counter. In the analysis of the data, specific binding is defined as the amount of $\left[{ }^{125} \mathrm{I}\right]-\mathrm{MSH}$ bound to cells in the absence of unlabeled MSH compared to the amount bound in the presence of a 1,000-fold excess of unlabeled MSH.

Statistical analysis. The $t$ test was used for statistical analyses.

\section{Results}

Effect of MSH and IFN- $\alpha, I F N-\beta$, and IFN- $\gamma$ on melanin production. Consistent with our earlier studies $(17,18), \mathrm{JB} / \mathrm{MS}$ melanoma cells were highly responsive to $\mathrm{MSH}$ treatment (Table I); they increased their melanogenic activity $>25$-fold after $4 \mathrm{~d}$ of treatment with the hormone. On the other hand, 
Table I. Titration of IFN- $\alpha, I F N-\beta$, and IFN- $\gamma$ Effects on MSH-induced Melanin Formation

\begin{tabular}{|c|c|c|c|c|}
\hline \multirow{2}{*}{$\begin{array}{l}\text { Addition to } \\
\text { medium }\end{array}$} & \multicolumn{2}{|c|}{ Cell number $\left(\times 10^{-6} /\right.$ flask $)$} & \multicolumn{2}{|c|}{ Melanogenic activity } \\
\hline & Without MSH & With MSH & Without MSH & With MSH \\
\hline & & & \multicolumn{2}{|c|}{ pmol/10 cells/16 h } \\
\hline None & $21 \pm 2$ & $20 \pm 1$ & $50 \pm 5$ & $1,383 \pm 213$ \\
\hline IFN- $\alpha(0.1)$ & $21 \pm 1$ & $21 \pm 2$ & $45 \pm 3$ & $1,798 \pm 175$ \\
\hline IFN- $\alpha(1)$ & $21 \pm 1$ & $20 \pm 11$ & $55 \pm 3$ & $2,318 \pm 388^{*}$ \\
\hline IFN- $\alpha(10)$ & $19 \pm 1$ & $19 \pm 2$ & $53 \pm 5$ & $2,573 \pm 350^{*}$ \\
\hline IFN- $\alpha(100)$ & $15 \pm 2^{*}$ & $15 \pm 1^{*}$ & $55 \pm 3$ & $2,458 \pm 375^{*}$ \\
\hline IFN- $\beta(0.1)$ & $20 \pm 2$ & $20 \pm 1$ & $33 \pm 3^{*}$ & $1,503 \pm 113$ \\
\hline IFN- $\beta(1)$ & $21 \pm 2$ & $21 \pm 1$ & $28 \pm 3^{*}$ & $2,225 \pm 175^{*}$ \\
\hline IFN- $\beta(10)$ & $19 \pm 1$ & $19 \pm 2$ & $30 \pm 3^{*}$ & $2,448 \pm 200^{*}$ \\
\hline IFN- $\beta(100)$ & $18 \pm 1$ & $18 \pm 1$ & $23 \pm 3^{*}$ & $1,780 \pm 138^{*}$ \\
\hline IFN- $\gamma(0.1)$ & $21 \pm 2$ & $21 \pm 1$ & $43 \pm 8$ & $1,645 \pm 188$ \\
\hline IFN- $\gamma(1)$ & $21 \pm 2$ & $21 \pm 1$ & $33 \pm 3^{*}$ & $1,783 \pm 75$ \\
\hline IFN- $\gamma(10)$ & $15 \pm 1^{*}$ & $15 \pm 1^{*}$ & $30 \pm 3^{*}$ & $1,208 \pm 38$ \\
\hline IFN- $\gamma(100)$ & $14 \pm 1^{*}$ & $14 \pm 1^{*}$ & $20 \pm 3^{*}$ & $310 \pm 75^{*}$ \\
\hline
\end{tabular}

$6 \times 10^{5} \mathrm{JB} / \mathrm{MS}$ cells were seeded in $75-\mathrm{cm}^{2}$ flasks and $1 \mathrm{~d}$ later the media were changed to include IFN (at IU $/ \mathrm{ml}$ ) as indicated and MSH (at $2 \times 10^{-7} \mathrm{M}$ ) where noted; appropriate media were changed daily. After $4 \mathrm{~d}$, the cells were harvested, counted, solubilized, and melanogenic activities were determined as detailed in Methods. The results are expressed as the means of picomoles $\left[{ }^{14} \mathrm{C}\right]$ tyrosine incorporated into melanin in triplicate assays $\pm \mathrm{SEM} ;{ }^{*}$ indicates a significant difference from the relevant control (on the top row) at $P$ $<0.05$ or better.

treatment with IFN- $\alpha$, IFN- $\beta$, or IFN- $\gamma$ alone did not signifcantly increase pigment production, but rather, IFN- $\alpha$ had no significant effect at any concentration tested, whereas IFN- $\beta$ or IFN- $\gamma$ elicited dose-dependent decreases in melanogenic activity. When the cells were cultured with IFN in the presence of MSH however, melanin production was clearly synergistically stimulated relative to cells treated with $\mathrm{MSH}$ alone (except at the higher concentrations of IFN- $\gamma$ ); the optimal concentration for this stimulatory effect of MSH response for each IFN was $1-10 \mathrm{IU} / \mathrm{ml}$.

As can also be seen from the data in Table I, neither MSH nor any of the IFN (at concentrations of 1 or $0.1 \mathrm{IU} / \mathrm{ml}$ ) had any effect on cell growth during the 4-d time course of these experiments. However, IFN- $\alpha$, IFN- $\beta$, or IFN- $\gamma$ at $10 \mathrm{IU} / \mathrm{ml}$ and above had slight antiproliferative effects on JB/MS cells; we thus routinely used IFN at $1 \mathrm{IU} / \mathrm{ml}$ as the optimal concentration to stimulate melanin production but to avoid effects on the growth potential of the cells. In other experiments (not shown), IFN- $\gamma$ was shown to have similar effects on the proliferation of B16 cells, whereas S91 cells were resistant to IFNinduced growth inhibition at concentrations as high as 100 $\mathrm{IU} / \mathrm{ml}$.

In a time course study, we examined the kinetics of the responses to MSH and IFN (Table II). When the cells were treated with IFN- $\alpha$, IFN- $\beta$, or IFN- $\gamma$ alone, the melanogenic activity at each time point was not significantly altered compared with the control. The relatively low levels of pigment production by these cells at days 1 through 3 increased as they approached confluence and began spontaneous pigmentation at days 4 and 5 . After subculture of the confluent cells at day 4, melanogenic activity decreased as the cells began to proliferate, and production of pigment slowly returned to basal levels. Note that the melanogenic activity of control cells, and the IFN treated cells, at day 1 was higher than at days 2 and 3; this was caused by residual melanogenic activity in the cell population used to initially seed the flasks.

The response of JB/MS cells to MSH was rapid; a significant increase in demonstrable melanogenic activity occurred within $1 \mathrm{~d}$, by which time it had doubled. The differences between the melanogenic potentials of control cells and MSH treated cells increased rapidly thereafter, was stimulated 6-fold by day 2 , and 38 -fold by day 3 (when the effect was most pronounced). The levels of melanin production in MSHtreated cells were highest on day 5 and, surprisingly, decreased thereafter until day 7 , even though these cells were treated with MSH continuously.

The responses of JB/MS cells to treatment with $\mathrm{MSH}$ and IFN- $\alpha$, IFN- $\beta$, or IFN- $\gamma$ in this experiment showed that melanogenic activities were significantly increased over MSH alone by day 2 , and that by day 4 were $15-60 \%$ higher (Table II). Perhaps more importantly, in cells treated with MSH and IFN the decreases in melanogenic activity after subculturing of the cells were significantly less pronounced, especially on day 7, where the melanogenic potentials of MSH and IFN treated cells were 7-8 times higher than those of MSH treated cells. Virtually identical results were obtained in experiments testing the effects of IFN- $\gamma$ and/or MSH on B16 and S91 cells (not shown), although the effects were somewhat less pronounced with $\mathrm{S} 91$ cells.

Flow cytometric analysis. To characterize the mechanism by which IFN stimulated melanogenic potential, we initially determined whether treatment with IFN elicited increases in the levels of tyrosinase produced by the cells. To do this, we used flow cytometric analysis, fixing and permeabilizing the cells, and then staining them with TMH-1, a MAb specific for

Table II. Time Course of the Effects of MSH and IFN- $\alpha, I F N-\beta$, and IFN- $\gamma$ on Melanin Production

\begin{tabular}{|c|c|c|c|c|c|c|c|c|c|}
\hline \multirow[b]{3}{*}{ Day } & \multirow[b]{3}{*}{ Cell number } & \multicolumn{8}{|c|}{ Melanogenic activity } \\
\hline & & \multicolumn{4}{|c|}{ Without MSH treatment } & \multicolumn{4}{|c|}{ With MSH treatment } \\
\hline & & None & IFN- $\alpha$ & IFN- $\beta$ & IFN- $\gamma$ & None & IFN- $\alpha$ & IFN- $\beta$ & IFN- $\gamma$ \\
\hline & $\times 10^{-6} /$ flask & \multicolumn{8}{|c|}{ pmol/10 cells $/ 16 \mathrm{~h}$} \\
\hline 1 & $1.7 \pm 0.2$ & 38 & 45 & 38 & 40 & 83 & 73 & 68 & 48 \\
\hline 2 & $9.8 \pm 0.5$ & 25 & 28 & 25 & 25 & 163 & 228 & 270 & 218 \\
\hline 3 & $17.8 \pm 1.3$ & 25 & 28 & 33 & 28 & 945 & 1,503 & 1,030 & 1,063 \\
\hline 4 & $21.9 \pm 1.0$ & 45 & 68 & 90 & 50 & 1,488 & 2,380 & 2,215 & 1,713 \\
\hline 5 & $0.6 \pm 0.1$ & 190 & 238 & 170 & 193 & 1,570 & 2,305 & 1,985 & 2,030 \\
\hline 6 & $1.9 \pm 0.2$ & 133 & 125 & 108 & 73 & 1,345 & 2,150 & 2,138 & 1,258 \\
\hline 7 & $5.2 \pm 0.4$ & 43 & 25 & 18 & 30 & 143 & 1,128 & 1,008 & 1,188 \\
\hline 8 & $15.1 \pm 1.5$ & 35 & 23 & 25 & 48 & 473 & 1,418 & 805 & 1,300 \\
\hline 9 & $18.7 \pm 1.0$ & 45 & 50 & 45 & 35 & 1,273 & 2,580 & 2,343 & 1,880 \\
\hline
\end{tabular}

The experimental protocol was as noted for Table I; flasks of cells were harvested daily for determination of melanogenic activity, and remaining flasks were subcultured at day 4 . Again, the appropriate media were changed daily; MSH was used at $2 \times 10^{-7} \mathrm{M}$ and IFN at $1 \mathrm{IU} / \mathrm{ml}$. The data are expressed as in Table I; for the sake of simplifying the table, standard errors are not reported but were $< \pm 15 \%$ in all cases. Cell numbers are expressed as the average of the flasks on each day; there were no significant differences between the cell numbers in controls, cells treated with MSH, or cells treated with IFN, at any time point assayed. 
Table III. Flow Cytometric Analysis of Tyrosinase Concentration in Melanoma Cells

\begin{tabular}{lcc}
\hline & \multicolumn{2}{c}{ Mean fluorescence intensity } \\
\cline { 2 - 3 } Treatment & Without MSH & $2 \times 10^{-7}$ M MSH \\
\hline None & 482 & 480 \\
IFN- $\alpha$ & 485 & 458 \\
IFN- $\beta$ & 475 & 460 \\
IFN- $\gamma$ & 463 & 472 \\
\hline
\end{tabular}

The experimental protocol was as detailed in Table I; cells growing for $4 \mathrm{~d}$ in media supplemented with IFN (at $1 \mathrm{IU} / \mathrm{ml}$ ) as noted, were harvested with EDTA, permeabilized with ethanol, and stained by indirect immunofluorescence with the tyrosinase specific MAb TMH- 1 as detailed in Methods. The data are expressed as mean fluorescence intensity determined by flow cytometry; background controls without the first antibody had a mean fluorescence intensity of 320.

the predominant, enzymatically active form of tyrosinase (18, 25). In Table III, data are shown on the intracellular tyrosinase concentrations of untreated, MSH-treated, and/or IFN-treated JB/MS melanoma cells. The mean fluorescence intensity of the untreated JB/MS melanoma cells was 482 after $4 \mathrm{~d}$ in culture; cells treated with MSH, or with IFN- $\alpha$, IFN- $\beta$, or IFN- $\gamma$ had no significant difference in enzyme levels, even
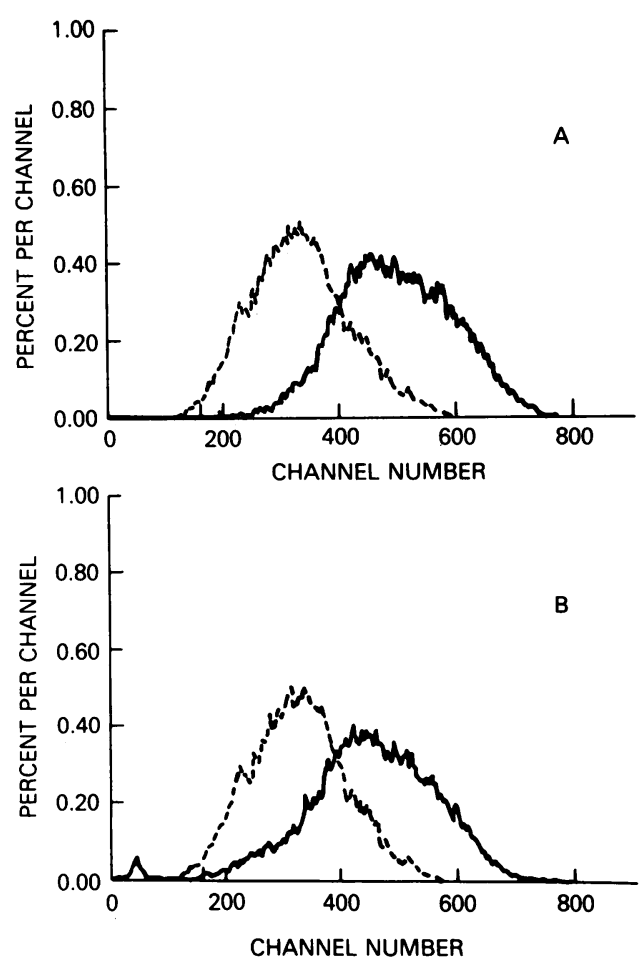

Figure 1. Flow cytometry of JB/MS cells labeled with anti-tyrosinase MAb. JB/MS melanoma cells were harvested, fixed, permeabilized, and stained with TMH-1 antibodies as detailed in Methods; in each figure, the curve on the left (---) is the negative control, the curve on the right $(-)$ is the specific staining pattern. $(A)$ Cells grown $4 \mathrm{~d}$ in DME. $(B)$ Cells grown $4 \mathrm{~d}$ in DME containing IFN- $\gamma(1 \mathrm{IU} / \mathrm{ml})$ and MSH $\left(2 \times 10^{-7} \mathrm{M}\right)$. when MSH and IFN were used at the same time. Fig. 1 shows histograms of two of these cell populations; there was no difference in the shape and intensity of the specific histograms between control cells (Fig. $1 A$ ) and MSH- and IFN- $\gamma$ treated cells (Fig. $1 B$ ). These data demonstrate that the action of MSH and IFN is not at the level of stimulating synthesis of tyrosinase, which agrees with our previous observations for response to MSH based on metabolic labeling and immunoprecipitation analyses (18), and also with studies from other laboratories that used enzymatic criteria $(20,29)$.

Synthesis and purification of biologically active iodinated $M S H$. We next examined the possibility that the stimulatory effects on melanin production elicited by IFN only in the presence of MSH resulted from increased hormonal stimulation due to modulation of the expression of surface MSH receptors. To perform such studies, an MSH receptor binding assay had to be optimized. In HPLC analysis of iodinated MSH (Fig. 2), two radioactive peaks eluted after the residual unlabeled MSH (peaks II and III). The radioactive peak (peak II) that eluted immediately after the unlabeled MSH peak (peak I) was confirmed by amino acid analysis (not shown) to be monoiodinated MSH (peak II). The production of biologically active $\left[{ }^{125} \mathrm{I}\right]-\mathrm{MSH}$ has been a point of contention in the literature for some time $(30,31)$; it was suggested that the denaturation of the iodinated peptide resulted from the oxidation of methionine during the iodination procedure (32). The amino acid analyses demonstrated that reduction with DTT immediately after iodination preserves the methionine residue, and that the radioactive fraction eluting after the unlabeled MSH was authentic $\left.{ }^{125} \mathrm{I}\right]-\mathrm{MSH}$ (peak II). The results in Table IV demonstrate that the biological activity of the iodinated MSH was preserved; the labeled MSH is equivalent to the original unlabeled MSH (at many different concentrations) in the ability to stimulate melanin production, that is, tyrosinase activity.

$M S H$ binding studies. In a time course study examining the rate of binding of labeled MSH to JB/MS cells (Fig. 3), $90 \%$ of maximal binding was observed within $1 \mathrm{~h}$, and thus a $2 \mathrm{~h}$

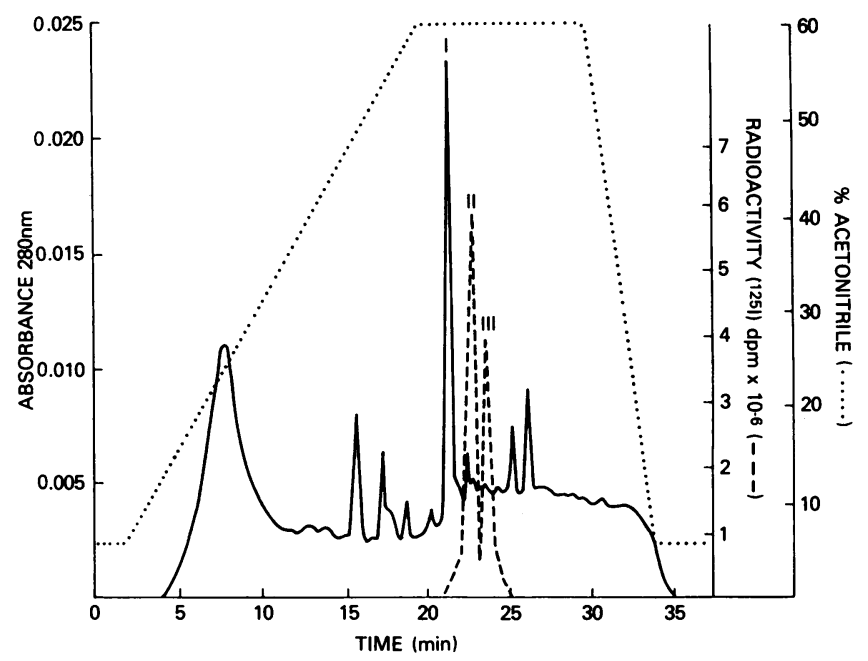

Figure 2. HPLC elution profile of MSH and iodinated MSH. MSH was iodinated, reduced, and partially purified on a Sephadex G10 column, as detailed in Methods. $100 \mu \mathrm{l}$ of the solution was resolved on a $\mathrm{C} 18$ column using an acetonitrile gradient, and monitored by $A_{280}$. 30-s fractions were collected and radioactivity was quantitated in a $\gamma$ counter. 
Table IV. Melanogenic Stimulating Capacity of HPLC-purified MSH

\begin{tabular}{|c|c|c|}
\hline \multirow[b]{2}{*}{ Concentration } & \multicolumn{2}{|c|}{ Tyrosinase Activity } \\
\hline & $\begin{array}{c}\text { Peak I } \\
\text { Unlabeled MSH }\end{array}$ & $\begin{array}{c}\text { Peak II } \\
{\left[{ }^{125} \mathrm{I}\right]-\mathrm{MSH}}\end{array}$ \\
\hline$n M$ & \multicolumn{2}{|c|}{$\mathrm{pmol} / 10^{5} \mathrm{cells} / \mathrm{h}$} \\
\hline 0.0 & \multicolumn{2}{|c|}{$488 \pm 50$} \\
\hline 0.4 & $1,325 \pm 63$ & $875 \pm 38$ \\
\hline 1.6 & $1,775 \pm 54$ & $1,688 \pm 50$ \\
\hline 6.3 & $3,025 \pm 30$ & $3,088 \pm 15$ \\
\hline 25.0 & $3,250 \pm 25$ & $3,213 \pm 10$ \\
\hline 100.0 & $3,219 \pm 28$ & $3,250 \pm 19$ \\
\hline 400.0 & $3,269 \pm 41$ & $3,238 \pm 31$ \\
\hline
\end{tabular}

Purified synthetic MSH was iodinated and separated by HPLC as detailed in Methods; aliquots of peaks I and II (Fig. 2) were used in culture media for JB/MS melanoma cells for $4 \mathrm{~d}$ at the concentrations noted. The cells were then harvested, solubilized, and assayed for tyrosinase activity as detailed in Methods. The data reported are the means of picomoles tyrosine hydroxylated determined by assays carried out in triplicate \pm SEM.

incubation time was used in all subsequent studies. In this experiment, $\sim 60-70 \%$ of the binding of $\left[{ }^{125} \mathrm{I}\right]-\mathrm{MSH}$ was blocked by the addition of a 1,000-fold excess of unlabeled MSH.

We next investigated the binding of MSH to IFN-treated $\mathrm{JB} / \mathrm{MS}$ cells. In this study, JB/MS cells either were untreated, or were treated for $4 \mathrm{~d}$ with IFN- $\alpha$, IFN- $\beta$, or IFN- $\gamma$; at the end of this period, the cells were examined for binding of labeled MSH. The results in Fig. 4 show that treatment with each of the IFN significantly increased the specific binding of hormone as follows: IFN- $\alpha$ by $46 \%$, IFN- $\beta$ by $43 \%$, and IFN- $\gamma$ by $34 \%$.

To determine if the increased binding was due to an increased affinity of the surface receptors for the hormone, or due to an increase in the number of receptors, we examined the binding of MSH (at various concentrations) to untreated $\mathrm{JB} / \mathrm{MS}$ cells, and to JB/MS cells that had been treated $4 \mathrm{~d}$ with IFN- $\alpha$, IFN- $\beta$, or IFN- $\gamma$. The $\left[{ }^{125} I\right]-M S H$ binding curves show that specific binding was essentially saturated at $128-260 \mathrm{nM}$ in untreated cells (Fig. 5, inset). The specific binding of the labeled hormone at the various concentrations was analyzed by Scatchard plots (Fig. 5). The Scatchard analyses of IFNtreated and untreated cells fell on straight lines, which indicates that the receptors on both types of cells possess a single affinity for the ligand; IFN- $\alpha$ and IFN- $\gamma$ gave essentially identical curves to the IFN- $\beta$ curve shown in Fig. 5 (data not shown). An average of three independent experiments yielded an equilibrium dissociation constant $\left(K_{\mathrm{d}}\right)$ of $2.2 \times 10^{-8} \mathrm{M}$ for MSH binding to untreated JB/MS cells, with $\sim 61,200 \pm 7,500$ binding sites per cell. JB/MS cells treated with IFN for $4 \mathrm{~d}$ had the following $K_{\mathrm{d}}$ and number of binding sites per cell: IFN- $\alpha$ $\left(5.5 \times 10^{-8} \mathrm{M}, 143,200 \pm 9,500\right)$, IFN- $\beta\left(4.6 \times 10^{-8} \mathrm{M}\right.$, $138,500 \pm 6,500)$, and IFN- $\gamma\left(3.3 \times 10^{-8} \mathrm{M}, 107,800 \pm 3,000\right)$. Thus each of the IFN increased the $K_{d}$ and the number of binding sites for MSH $\sim 1.8-2.3$-fold $(P<0.001)$.

\section{Discussion}

This study has shown that JB/MS melanoma cells are highly responsive to $\mathrm{MSH}$ : levels of melanin production were stimulated 25 -fold within $4 \mathrm{~d}$ by the hormone (Table I), and tyrosinase activity was increased $>6$-fold (Table IV). Treatment of JB/MS cells with IFN- $\alpha$, IFN- $\beta$, or IFN- $\gamma$ has no significant direct effect on melanogenic activity, but when JB/MS cells are cultured in IFN in the presence of $\mathrm{MSH}$, melanogenic activity is synergistically stimulated relative to the level in cells treated with MSH alone. Examination of the kinetics of cellular responses to MSH alone, and to MSH with IFN, revealed that these effects occur rapidly, and that the effects of IFN are even more dramatic when the cells are subcultured (Table II). MSH- and IFN-treated cells maintained their high levels of melanogenic activity after subculturing, which at times was seven to eightfold greater than cells maintained in MSH alone, which was in turn fivefold greater than the level in untreated cells.

Previous studies have reported that both human rIFN- $\alpha$ A/D (at 30-3,000 IU/ml) (10) and murine L cell IFN (at 0.03-30 IU/ml) (11), inhibited both spontaneous and MSH-

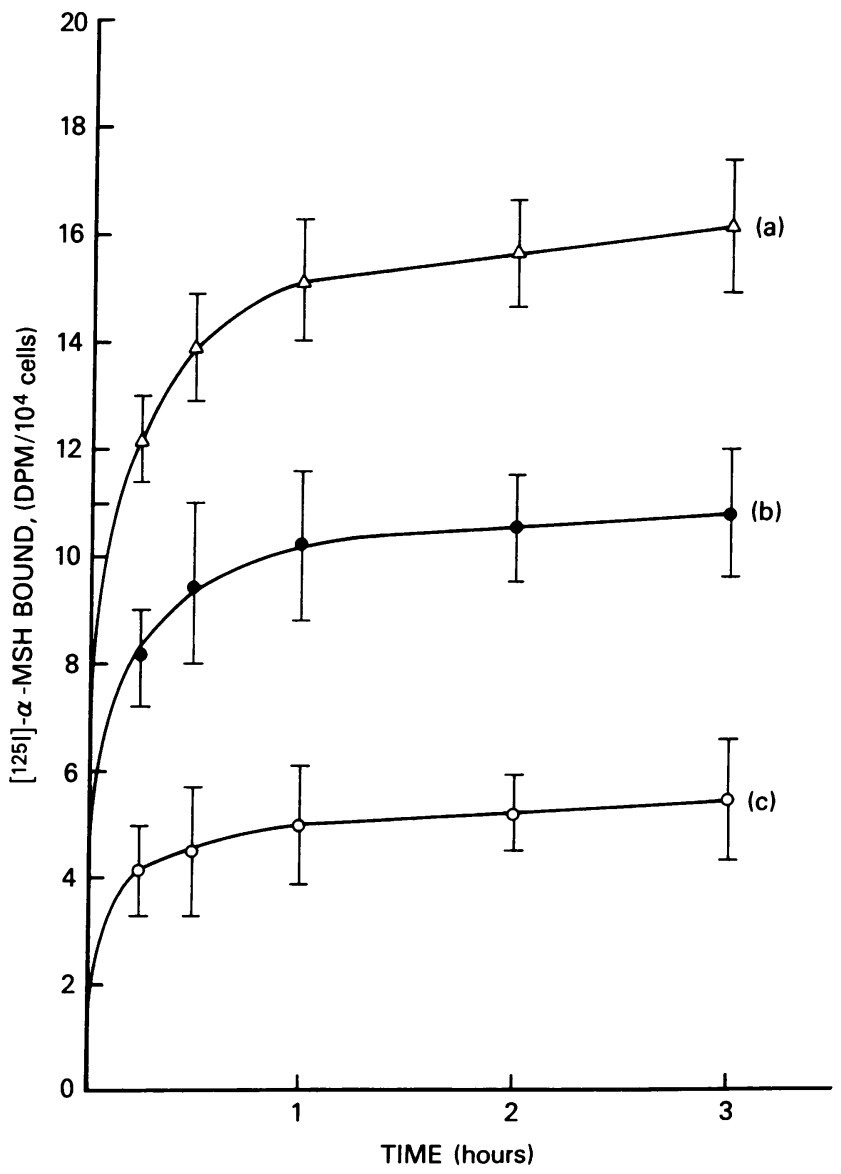

Figure 3. Time course of the binding of labeled MSH to JB/MS cells. JB/MS melanoma cells were incubated with labeling buffer containing [ $\left.{ }^{125} \mathrm{I}\right]-\mathrm{MSH}$ for different times at $4^{\circ} \mathrm{C}$ as noted, and specifically bound hormone was determined as detailed in Methods. The data points reported are the means of triplicate assays \pm SEM. $(A)$ Binding of $1 \mathrm{nM}\left[{ }^{125} \mathrm{I}\right]-\mathrm{MSH} ;(B)$ specific binding of [ $\left.{ }^{125} \mathrm{I}\right]-\mathrm{MSH}$ to cells; $(C)$ binding of $1 \mathrm{nM}\left[{ }^{125} \mathrm{I}\right]-\mathrm{MSH}$ in the presence of $1 \mu \mathrm{M}$ unlabeled MSH. 


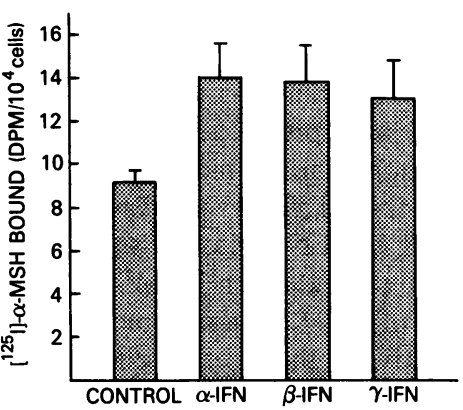

Figure 4. Binding of labeled MSH to untreated and IFN-treated JB/MS cells. JB/MS cells were seeded in flasks and $24 \mathrm{~h}$ later the medium was changed, and included either IFN as noted (at 1 $\mathrm{IU} / \mathrm{ml}$ ) or no addition. The media were changed daily, and on day 4 the cells were harvested and tested for expression of surface MSH receptors as detailed in Methods. The data shown are the specific binding of [ $\left.{ }^{125} \mathrm{I}\right]-\mathrm{MSH}$ determined in assays carried out in triplicate \pm SEM. The differences in binding for all three IFN-treated samples differed significantly from the controls at $P<0.01$.

stimulated melanin production in clones of B 16 murine melanoma cells, and L cell IFN had no antiproliferative effect on these cells. On the other hand, human $\operatorname{rIFN}-\gamma$ (at $100 \mathrm{IU} / \mathrm{ml}$ ) stimulated melanin production with a dose-dependent antiproliferative effect on the human melanoma cell line Colo 38 (6). In yet another study (7), human $\mathrm{rIFN}-\beta$ (at $2,000 \mathrm{IU} / \mathrm{ml}$ ) was reported to stimulate spontaneous melanin production in three out of four human melanoma cell lines, but had an antiproliferative effect on all four lines. The reasons behind such varied findings on the effects of IFN on pigmentation are not yet clear, but in light of the results presented in this paper, might reflect differences in $(a)$ the reactivities of various cell lines to the different IFN, $(b)$ the concentrations of IFN used, (c) the sensitivities of different cell lines to MSH, and/or (d) the densities of the cell populations examined.

In our study, cell density was a critical factor that affected the melanogenic activity of JB/MS melanoma cells (Table II). Spontaneous melanin production was lowest when the cell extract was prepared from cells in the midexponential phase of growth (on days 2 and 3), and increased progressively thereafter. By day 5 in our experiments, when the cells were confluent, the melanogenic activity in untreated cells was seven times higher than on day 2 . After subculturing of the cells, the melanogenic potential decreased again towards background levels. When the cells were treated with MSH, stimulation of melanin production was evident within $24 \mathrm{~h}$ (at which time it had doubled) and was highest on day 5. However, even when the cells were continually exposed to $\mathrm{MSH}$, the melanogenic activity decreased rapidly after subculturing of the cells on day 5 , and also reached its lowest point at day 7 . From that point on, similar to the control cells, melanogenic activity increased again until day 9 . An interesting contrast to this was the maintenance of high levels of melanin production after subculturing when the cells were kept in IFN-containing media. In light of the effect IFN has on the expression of surface MSH receptors, it would seem most likely that this effect is modulated through the continued expression of increased numbers of surface MSH receptors, even in rapidly proliferating cells. Although this has not yet been directly confirmed, the potential significance of this effect on mammalian melanogenesis in vivo, where melanocytes are constantly exposed to MSH and are slowly, but continually growing, should not be overlooked. Although an inhibitory effect of MSH on melanoma cell growth has been previously reported $(21,22)$, such an effect was not seen within the 9-d course of our experiments with JB/MS cells, or in similar studies we have performed using B16 or S91 melanoma cells (not shown).

In related studies, we have found that the expression of surface MSH receptors by melanoma cells is an unstable phenotype, but is of critical importance to its state of differentiation. In those studies (not shown), we have cloned pigmented and nonpigmented populations of melanoma cells and have found a direct correlation of their pigmentation with their ability to respond to $\mathrm{MSH}$, and with their expression of surface MSH receptors. The increased expression of surface MSH receptors is lost within several serial passages of cloned cells so that continual passage of melanoma cells rapidly results in a relatively MSH nonresponsive line; such an unstable phenotype may also help explain the variability noted in previous studies on the effects of IFN and pigmentation.

When JB/MS melanoma cells were cultured with MSH, or with MSH and IFN, melanogenic activity was significantly increased. To understand the mechanism of this phenomenon, we investigated the intracellular tyrosinase concentrations using flow cytometry and a tyrosinase-specific MAb, TMH-1. If the cells were responding to MSH and/or to IFN by increasing production of the enzyme, or by stabilizing existing enzyme, one would expect that the specific fluorescence of the cells would increase. However, our results clearly show that this is not the case. The results of this study are also consistent with our other studies using S91 and B16 cells responding to MSH, which have shown that the mechanism of melanocytic response to this hormone does not require increases in synthesis of tyrosinase $(17,18)$. The results of those studies indicated that increases in enzymatic activity result primarily from the activation of a preexisting pool of inactive enzyme rather than from synthesis of new enzyme; similar conclusions have been reached in studies using enzymatic methodologies $(20,29)$.

Our MSH binding studies demonstrated that IFN increased the expression of surface MSH receptors on the JB/MS cells significantly. Analysis of the binding data by Scatchard analysis showed $>$ twofold increase in the number of binding sites for MSH on IFN-treated cells, which was accomplished with no apparent change in the affinity of the receptors for

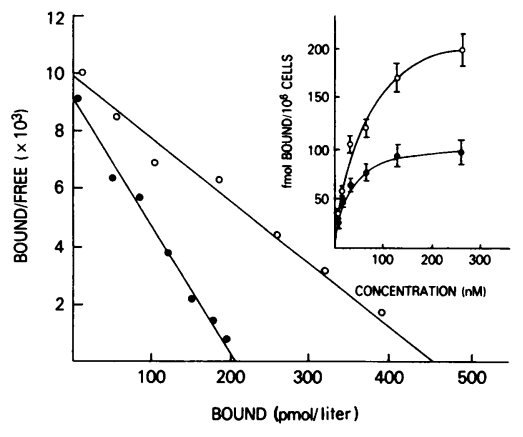

Figure 5. Scatchard analysis of MSH binding to JB/MS melanoma cells. JB/MS cells were seeded in flasks and $24 \mathrm{~h}$ later the medium was changed to include IFN- $\beta$ (at 1 $\mathrm{IU} / \mathrm{ml}$ ) or no addition. Media were changed daily, and on day 4 the cells were harvested and tested for expression of surface MSH receptors as detailed in Methods, using labeled hormone at concentrations ranging from 1 to $260 \mathrm{nM}$. The data represent specifically bound ligand and are presented as the ratio of cellbound to unbound (free) $\left[{ }^{125} \mathrm{I}\right]-\mathrm{MSH}$ versus the concentration of cellbound $\left[{ }^{125} \mathrm{I}\right]-\mathrm{MSH}$. Each data point represents the average of three independent assays, the variation between the assays was always $<20 \%$. (๑) untreated cells; (0) IFN- $\beta$ treated cells. (Inset) [ ${ }^{125}$ I]-MSH binding saturation curves. 
MSH ( $K_{\mathrm{d}}$ of $2.2 \times 10^{-8} \mathrm{M}$ ), since a two or threefold difference in $K_{\mathrm{d}}$ is relatively insignificant. These results suggest that the increase in MSH binding occurred through a stimulation of the expression of surface MSH receptors. The number of MSH receptors on untreated JB/MS melanoma cells was very similar to the number recently reported for M2R melanoma cells (a clone of B16), which had 75,000 MSH receptors per cell and a $K_{\mathrm{d}}$ of $2 \times 10^{-8} \mathrm{M}$ (33). This increase in the expression of MSH receptors was followed by increased cellular tyrosinase activity and melanin production when the cells were treated with the hormone. Although IFN treatment alone increased the expression of MSH receptors on the cell surface, there was no increase in tyrosinase activity in the absence of exogenously added MSH; our data further show that an increase in MSH receptors alone is not sufficient to increase cellular pigmentation. Although these results clearly show that IFN treatment elicits an increase in the number of surface MSH receptors, it is possible that IFN treatment in the presence of MSH would be even greater than IFN alone in stimulating the number of surface MSH receptors (even though the two to threefold increase noted was consistent with the increase found in melanogenic activity). To investigate this possibility, it would be necessary to measure the number of MSH receptors on cells grown in the presence of IFN and MSH, which is currently impossible because we are unable technically to accurately measure the number of occupied MSH receptors.

IFN- $\gamma$ has been shown to induce HLA-DR expression in a wide variety of cell types $(34,35)$ including melanoma cells (36), and to increase the expression of melanoma-associated antigens in human melanoma cell lines $(6,37)$. On the other hand, the expression of some other melanoma-associated antigens was reduced after treatment with IFN- $\gamma$ (6). IFN (and especially IFN- $\gamma$ ) thus have been reported to modulate the expression of surface antigens. IFN treatment has also been shown to alter cell surface properties, for example, charge (38), mobility of ligand receptors (39), binding of lectins (40), architecture (41), and exposure of gangliosides (42). Thus, modulating effects of IFN on the cell surface have been widely reported, and are consistent with this study, showing that IFN stimulates surface MSH receptor expression on melanoma cells. The clinical responses of melanoma to treatment with IFN are thought to result from immune defenses of the host that are potentiated by the alteration of antigen expression on the tumor cell surface, and by the induction of differentiation with a concomitant reduction in the malignancy of the tumor cells. The induced expression of MSH receptors on melanoma cells by IFN, the expression of which are critical to melanocyte differentiation, may be an important mode of action of the antitumor effect of IFN.

It has been recently reported that phosphorylated L-DOPA stimulates $\beta$-MSH binding capacity and responsiveness by $S 91$ melanoma cells (43), and that ultraviolet-B light caused an increase in [ $\left.{ }^{125} \mathrm{I}\right]-\beta$-MSH binding capacity and responsiveness by S91 cells (44). Those reports, and our results, suggest that increasing MSH receptor activity causes melanoma cells to have an increased sensitivity to treatment with MSH. Although a wide range in the binding capacity of $\left[{ }^{125} \mathrm{I}\right]-\mathrm{MSH}$ to various kinds of melanoma cells has been reported (45), it is only now becoming clear that there is a direct correlation between melanin production and MSH receptor activity (as noted above).
At this time, the causes of postinflammatory pigmentation have not been explained. Prostaglandins, especially PGE $_{1}$ (46-48), and histamine (49), have been reported to directly increase tyrosinase activity in murine and human melanoma cells. Those reports suggest that prostaglandins are important agents that may also be involved in postinflammatory pigmentation of the skin. Human IFN- $\beta$ has been shown to stimulate the synthesis of $\mathrm{PGE}_{1}$ and $\mathrm{F} 2 \alpha$ in human fibroblasts (50), and endogenously induced or exogenously added IFN stimulated prostaglandin formation by the cells of five species: mouse, hamster, chicken, monkey, and human (51). Therefore, it seems reasonable to expect that prostaglandins may be involved as intermediates in the effects of IFN on MSH receptor expression by melanoma cells. We have examined the effects of IFN- $\alpha$, IFN- $\beta$, and IFN- $\gamma$ on the synthesis of PGE by JB/MS cells, but thus far, have not been able to show a significant effect of IFN on the level of PGE (data not shown). More study is necessary, however, before definitive conclusions can be drawn about such interactions.

In sum, we have shown that physiologically low concentrations of IFN- $\alpha$, IFN- $\beta$, and IFN- $\gamma$ increase the expression of MSH receptors on the surface of melanoma cells, which in turn elicits an increase in their responsiveness to MSH. The synergistic effect of IFN and MSH on melanocyte differentiation has been shown for three different murine melanoma lines, which suggests that such a response might constitute a general phenomenon. These results suggest that IFN, which may be produced by infiltrating inflammatory cells, might play an important role in postinflammatory pigmentation of the skin, and demonstrate at least one mechanism whereby IFN stimulate differentiation of melanoma cells. This latter effect might in turn play a part in effecting the responses elicited by IFN treatment seen in clinical trials of melanoma treatment.

\section{Acknowledgments}

The authors wish to thank Genentech, Inc., for providing murine rIFN- $\gamma$, and Dr. Tohru Akaboshi, Department of Internal Medicine, Kitasato University School of Medicine, for his valuable discussion of various parts of this study.

\section{References}

1. Pestka, S. 1986. Induction of interferons. A. Human interferons. Methods Enzymol. 119:27-106.

2. Guerry, D., M. A. Alexander, D. E. Elder, and M. F. Herlyn. 1987. Interferon- $\gamma$ regulates the $T$ cell response to precursor nevi and biologically early melanoma. J. Immunol. 139:305-312.

3. Fisher, P. B., A. F. Miranda, L. E. Babiss, S. Pestka, and I. B. Weinstein. 1983. Opposing effects of interferon produced in bacteria and of tumor promoters on myogenesis in human myoblast cultures. Proc. Natl. Acad. Sci. USA. 80:2961-2965.

4. Hattori, T., M. Pack, P. Bougnoux, Z. L. Chang, and T. Hoffman. 1983. Interferon-induced differentiation of U937 cells: comparison with other agents that promote differentiation of human myeloid or monocyte like cell lines. J. Clin. Invest. 72:237-244.

5. Ball, E. D., P. M. Guyre, L. Shen, J. M. Glynn, C. R. Maliszewski, P. E. Baker, and M. W. Fanger. 1984. Gamma interferon induces monocytoid differentiation in the HL-60 cell line. J. Clin. Invest. 73:1072-1077.

6. Giacomini, P., L. Imberti, A. Aguzzi, P. B. Fisher, G. Trinchieri, 
and S. Ferrone. 1985. Immunochemical analysis of the modulation of melanoma-associated antigens by DNA recombinant immune interferon. J. Immunol. 135:2887-2894.

7. Fisher, P. B., D. R. Prignoli, H. Hermo, I. B. Weinstein, and S. Pestka. 1985. Effects of combined treatment with interferon and mezerein on melanogenesis and growth in human melanoma cells. $J$. Interferon Res. 5:11-22.

8. Blalock, J. E., and C. Harp. 1981. Interferon and adrencorticotropic hormone induction of steroidogenesis, melanogenesis and antiviral activity. Arch. Virol. 67:45-49.

9. Fisher, P. B., and S. Grant. 1985. Effects of interferon on differentiation of normal and tumor cells. Pharmacol. Ther. 27:143-166.

10. Fisher, P. B., H. Hermo, D. R. Prignoli, I. B. Weinstein, and S. Pestka. 1984. Hybrid recombinant human leucocyte interferon inhibits differentiation in murine B-16 melanoma cells. Biochem. Biophys. Res. Commun. 119:108-115.

11. Fisher, P. B., R. A. Mufson, and I. B. Weinstein. 1981. Interferon inhibits melanogenesis in B-16 mouse melanoma cells. Biochem. Biophys. Res. Commun. 100:823-830.

12. Foon, K. A., S. A. Sherwin, P. G. Abrams, H. C. Stevenson, P. Holmes, A. E. Maluish, R. K. Oldham, and R. B. Herberman. 1985. A phase I trial of recombinant gamma interferon in patients with cancer. Cancer Immunol. Immunother. 20:193-197.

13. Creagan, E. T., D. L. Ahmann, S. Frytak, H. J. Long, M. N. Chang, and L. M. Itri. 1986. Phase II trials of recombinant leukocyte A interferon in disseminated malignant melanoma: results in 96 patients. Cancer Treatment Rep. 70:619-624.

14. McLeod, G. R. C., D. B. Thomson, and P. Hersey. 1987. Recombinant interferon alfa-2a in advanced malignant melanoma. A phase I-II study in combination with DTIC. Int. J. Cancer. 1(Suppl):31-35.

15. Berkelhammer, J., R. W. Oxenhandler, R. R. Hook, Jr., and J. M. Hennessy. 1982. Development of a new melanoma model in C57BL/6 mice. Cancer Res. 42:3157-3163.

16. Berkelhammer, J., T. N. Luethans, R. R. Hook, Jr., and R. W. Oxenhandler. 1986. Phenotypic instability of mouse melanomas after propagation in vivo and in vitro. Cancer Res. 46:2923-2928.

17. Hearing, V. J., G. B. Cannon, W. D. Vieira, M. Jiménez, K. Kameyama, and L. W. Law. 1988. JB/MS murine melanoma: a new model for studies on the modulation of differentiation, and of tumorigenic and metastatic potential. Int. J. Cancer. 41:275-282.

18. Jiménez, M., K. Kameyama, Y. Tomita, and V. J. Hearing. 1988. Mammalian tyrosinase: biosynthesis, processing and modulation by melanocyte stimulating hormone. Proc. Natl. Acad. Sci. USA. 85:3830-3834.

19. Gray, P. W., and D. V. Goeddel. 1983. Cloning and expression of murine immune interferon cDNA. Proc. Natl. Acad. Sci. USA. 80:5842-5846.

20. Fuller, B. B., J. B. Lunsford, and D. S. Iman. 1987. $\alpha$-Melanocyte-stimulating hormone regulation of tyrosinase in Cloudman S-91 mouse melanoma cell cultures. J. Biol. Chem. 262:4024-4033.

21. Halaban, R., and A. B. Lerner. 1977. The dual effect of melanocyte-stimulating hormone (MSH) on the growth of cultured mouse melanoma cells. Exp. Cell Res. 108:111-117.

22. Abdel-Malek, Z. A., M. E. Hadley, M. D. Bregman, F. L. Meyskens, and V. J. Hruby. 1986. Actions of melanotropins on mouse melanoma cell growth in vitro. J. Natl. Cancer Inst. 76:857-863.

23. Hearing, V. J., and T. M. Ekel. 1976. Mammalian tyrosinase; a comparison of tyrosine hydroxylation and melanin formation. Biochem. J. 157:549-557.

24. Hearing, V. J. 1987. Mammalian monophenol monooxygenase (tyrosinase): purification, properties, and reactions catalyzed. Methods Enzymol. 142:154-163.

25. Tomita, Y., P. M. Montague, and V. J. Hearing. 1985. Anti$\mathrm{T}_{\mathbf{4}}$-tyrosinase monoclonal antibodies-specific markers for melanocytes. J. Invest. Dermatol. 85:426-430.

26. Lambert, D. T., and A. B. Lerner. 1983. Optimization of a melanotropin-receptor binding assay by reversed-phase high-performance liquid chromatography. J. Chromatogr. 266:567-576.

27. Bidlingmeyer, B. A., S. A. Cohen, and T. L. Tarvin. 1984. Rapid analysis of amino acids using pre-column derivatization. $J$. Chromatogr. 336:93-104.

28. Lambert, D. T., P. E. Whitcombe, G. E. Moellmann, and A. B. Lerner. 1985. Basic characterization of the receptor for MSH on Cloudman S91 melanoma cells. In Pigment Cell 1985. J. Bagnara, S. N. Klaus, E. Paul, and M. Schartl, editors. University of Tokyo Press, Tokyo. 165-174.

29. Wong, G., and J. M. Pawelek. 1975. Melanocyte-stimulating hormone promotes activation of pre-existing tyrosinase molecules in Cloudman S91 melanoma cells. Nature (Lond.). 255:644-646.

30. Lambert, D. T., and J. M. Varga. 1981. Iodination of melanotropin: production of biologically active ${ }^{125} \mathrm{I}-\alpha-\mathrm{MSH}$. In Pigment Cell 1981. M. Seiji, editor. University of Tokyo Press, Tokyo. 347-353.

31. Lambert, D. T., C. Stachelek, J. M. Varga, and A. B. Lerner. 1982. Iodination of $\beta$-melanotropin. J. Biol. Chem. 257:8211-8215.

32. Heward, C. B., Y. C. S. Yang, T. K. Sawyer, M. D. Bregman, B. B. Fuller, V. J. Hruby, and M. E. Hadley. 1979. Iodination associated inactivation of $\beta$-melanocyte stimulating hormone. Biochem. Biophys. Res. Commun. 88:266-273.

33. Gerst, J. E., J. Sole, J. P. Mather, and Y. Salomon. 1986. Regulation of adenylate cyclase by $\beta$-melanotropin in the M2R melanoma cell line. Mol. Cell Endocrinol. 46:137-147.

34. Kelley, V. E., W. Fiers, and T. B. Strom. 1983. Cloned human interferon- $\gamma$, but not interferon- $\beta$, or $-\alpha$, induces expression of HLADR determinants by fetal monocytes and myeloid leukemic cell lines. J. Immunol. 132:240-245.

35. Kameyama, K., T. Tone, H. Eto, S. Takezaki, T. Kanzaki, and S. Nishiyama. 1987. Recombinant gamma interferon induces HLADR expression on squamous cell carcinoma, trichilemmoma, adenocarcinoma cell lines, and cultured human keratinocytes. Arch. Dermatol. Res. 279:161-166.

36. Basham, T. Y., and T. C. Merigan. 1983. Recombinant $\gamma$-interferon induces HLA-DR synthesis and expression. J. Immunol. 130:1492-1494.

37. Kameyama, K., S. Takezaki, T. Kanzaki, and S. Nishiyama. 1986. HLA-DR and melanoma-associated antigen (p97) expression during the cell cycle in human melanoma cell lines, and the effects of recombinant gamma-interferon: two-color flow cytometric analysis. $J$. Invest Dermatol. 87:313-318.

38. Knight, E., Jr., and B. D. Korant. 1977. A cell surface alteration in mouse $\mathrm{L}$ cells induced by interferon. Biochem. Biophys. Res. Commun. 74:707-713.

39. Matsuyama, M. 1979. Action of interferon on cell membrane of mouse lymphocytes: inhibition of ligand-induced redistribution of surface receptors. Exp. Cell Res. 124:253-259.

40. Huet, C., I. Gresser, M. T. Mandu, and P. Lindahl. 1974. Increased binding of concanavalin A to interferon-treated murine leukemia L1210 cells. Proc. Soc. Exp. Biol. Med. 147:52-57.

41. Chang, E. H., F. T. Jay, and R. M. Friedman. 1978. Physical, morphological, and biochemical alterations in the membrane of AKR mouse cells after interferon treatment. Proc. Natl. Acad. Sci. USA. 75:1859-1863.

42. Grollman, E. F., G. Lee, S. Romas, P. S. Lazo, H. R. Kaback, R. M. Friedman, and L. D. Kohn. 1978. Relationships of the structure and function of the interferon receptor to hormone receptors and establishment of the antiviral state. Cancer Res. 38:4172-4185.

43. McLane, J., M. Osber, and J. M. Pawelek. 1987. Phosphorylated isomers of L-DOPA stimulate MSH binding capacity and responsiveness to MSH in cultured melanoma cells. Biochem. Biophys. Res. Commun. 145:719-725.

44. Bologna, J., M. Murray, and J. M. Pawelek. 1987. Evidence that UVB-induced melanogenesis is mediated through MSH receptors. J. Invest. Dermatol. 88:478A.

45. Libert, A., G. Ghanem, R. Arnould, A. Verammen-Grandjean, 
and F. Lejeune. 1985. Binding of the $\alpha$-melanocyte-stimulating hormone to human melanoma cells in culture. In Pigment Cell 1985. J. Bagnara, S. N. Klaus, E. Paul, and M. Schartl, editors. University of Tokyo Press, Tokyo. 175-181.

46. Kreiner, P. W., C. J. Gold, J. J. Keirns, W. A. Brock, and M. U. Bitensky. 1973. Hormonal control of melanocytes, MSH-sensitive adenyl cyclase in the Cloudman melanoma. Yale J. Biol. Med. 46:583-591.

47. Fuller, B. B., and J. Lebowitz. 1980. Decay of hormone responsiveness in mouse melanoma cells in culture as a function of cell density. J. Cell Physiol. 103:279-287.

48. Abdel-Malek, Z. A., V. B. Swope, N. Amornisiripanitch, and J. J. Nordlund. 1987. In vitro modulation of proliferation and melani- zation of S91 melanoma cells by prostaglandins. Cancer Res. 47:3141-3146.

49. Bernd, A., P. Altmeyer, G. Schäfer, W. Ch. Marsch, and H. Holzmann. 1986. Bleomycin enhances the tyrosinase activity of human malignant melanoma cells in culture. Pharmacol. Res. Commun. 18:1075-1091.

50. Fuse, A., I. Mahmud, and T. Kuwata. 1982. Mechanism of stimulation by human interferon of prostaglandin synthesis in human cell lines. Cancer Res. 42:3209-3214.

51. Fitzpatrick, F. A., and D. A. Stringfellow. 1980. Virus and interferon effects on cellular prostaglandin biosynthesis. J. Immunol. 125:431-437. 